\title{
Evaluation of Online Video Usage and Learning Satisfaction: An Extension of the Technology Acceptance Model
}

\author{
Judit T. Nagy \\ Department of Economics and Methodology Edutus College, Budapest, Hungary
}

\begin{abstract}
The aim of the study was to examine the determining factors of students' video usage and their learning satisfaction relating to the supplementary application of educational videos, accessible in a Moodle environment in a Business Mathematics Course. The research model is based on the extension of Technology Acceptance Model (TAM), in which the core TAM constructs - perceived usefulness, perceived ease of use, attitude - and internet self-efficacy were included as the explanatory factors of video usage. As regards the determinants of learning satisfaction, beside the core TAM constructs, the role of learning performance, learner-learner interaction, and learner-teacher interaction was examined. Data were collected from 89 students using a questionnaire, on which the partial leastsquares structural equation modelling approach was used to evaluate the research model. The results confirmed that perceived usefulness, attitude, and internet self-efficacy had a direct effect on the video usage. Learning satisfaction was directly influenced by learner-learner interaction, perceived ease of use, and learning performance. Furthermore, the results indicated that video usage had a significant effect both on learning performance and on learning satisfaction. The findings show that the extended TAM model can be applied for predicting the university students' video technology usage and their learning satisfaction regarding the usage.
\end{abstract}

Keywords: video usage, learning satisfaction, learning performance, technology acceptance model

\section{Introduction}

Thanks to the development of video technolgy and the Internet, as well as the development of multimedia reproduction devices, using video as a web-based multimedia device has become more and more widespread. Nowadays, several institutions offer online educational materials including video. Students can have rapid access to these materials anywhere and any time.

The numerous available technologies have lead to numerous possibilities for their use, therefore the way in which video technologies can be integrated into education is a serious question for both the management and the teachers. As a result it has become indispensible to evaluate the use of educational videos in different way. 
To create successful strategies, it is essential to estabilish how to use instructional media in the most efficient way with the aim of engancing learning (Koohang \& Durante, 2003). For planning an efficient learner-centered electronic learning environment, apart from the cognitive factors, we must have a better understanding of the students' and behaviour as well as the factors influencing them (Abbad, Morris, \& Nahlik, 2009; Giannakos, Chorianopoulos, \& Chrisochoides, 2015; Grandon, Alshare, \& Kwan, 2005; McConville \& Lane, 2006). Therefore research into students' feelings and behaviour linked to video usage is needed. These investigations can provide the management with information that lays the foundation of decision-making (Al-Gahtani, 2016), which is essential because of the high production costs of educational videos (Donkor, 2010).

The aim of the present study was, on the one hand, to analyze the correlation of the factors influencing the university students' video usage and their learning satisfaction. On the other hand, with the help of the elaborated model, a theoretical framework is offered that could be suitable for assesing the video technology usage and the learning satisfaction of the university students. The results will contribute to the successful educational video usage for management and teachers alike.

The model used in the present study was based on the Technology Acceptance Model (TAM). The current research was carried out in a higher-level mathematics course at a College of Business located in Hungary. Besides traditional classroom teaching and electronic textbooks, the students had access to online educational videos available in a Moodle environment. The 10-15 minute long, problem-based educational videos had been recorded by the teachers and the step-by-step solution of each task was demonstrated on a split-screen display.

With Moodle, the students were able to communicate electronically with their group-mates and the teachers using forum participation and message sending.

\section{Literature Review and Research Model}

\section{Videos in Education}

The exclusive dominance of educational media such as speech and written textbooks lasting for many decades was overthrown by the appearance of visual and audiovisual media and by their integration into education in the twentieth century. There are more and more examples world-wide for using video technology in the area of organized training. The means of usage and the applied videos are varied. The selection of video type, for example, is influenced by the course content or the level of expenditure. However, Lonn-Teasley (2009) raise a serious question: How does video technology influence teaching and learning?

In the course of evaluation, examining the cognitive factors, such as learning performance, is of primary importance, but analysing the affective factors, such as learning satisfaction and the behaviour linked to it, is also important. (Noel-Levitz, 2011; Palmer \& Koenig-Lewis, 2012).

The studies into learning performance don't show consistent results. Some researchers say video usage doesn't have a significant effect on learning performance or the effect is not clear (DeVaney, 2009; Figlio, Rush, \& Yin, 2010; Kim \& Chen, 2011). In contrast, several studies have shown that video usage 
has a significant positive effect on learning performance (Dalal, 2014; Day \& Foley, 2006; Dupuis, Coutu, \& Laneuville, 2013; Kay \& Kletskin, 2012; Kurtz, Fenwick Jr., \& Ellsworth, 2007; Lloyd \& Robertson, 2012 Traphagan, Kucsera, \& Kishi, 2010; Vajoczk, Watt, Marquis, \& Holshausen, 2010; Wieling \& Hofman, 2010; Williams, Birch, \& Hancock, 2012; Yunus et al., 2006; Zhang, Zhou, Briggs, $\&$ Nunamaker, 2006). No result supporting any negative effect is available.

Affective examinations into video usage have been published since 2006 (Chester, Buntine, Hammond, \& Atkinson, 2011). These studies analyze student statisfaction, sudent attitude, or student behaviour. In descriptive attitude studies where students can use videos optionally along with live lectures, the researchers find that students have a positive attitude and they advise such courses supported by videos to fellow students (Copley, 2007; Dupagne, Millette, \& Grinfeder, 2009; Hill \& Nelson, 2011; Kelly, Lyng, McGrath, \& Cannon, 2009; Williams, Birch, \& Hancock, 2012). In the case of satisfaction studies unrelated to the means of usage, most of the students are satisfied (Soong, Chan, Cheers, \& Hu, 2006; Gosper et al., 2007). There are comperative examinations as well in which researchers point out that the video enhances learning satisfaction compared both to traditional education (King \& He, 2006; Schepers \& Wetzels, 2007; El-Sayed \& El-Sayed, 2013) and to traditional, video-free, text-based elearning (Choi \& Johnson, 2007).

The behaviour and attitude studies where students are provided with optional videos along with live lectures show that the students most frequently use the available videos (1) to make up the missed lectures (McElroy \& Blount, 2006; Traphagan, Kucsera, \& Kishi, 2010); (2) to supplement the live lectures (Evans, 2008; Lonn \& Teasley, 2009; McElroy \& Blount, 2006; Traphagan, Kucsera, \& Kishi, 2010); and (3) to get specially prepared for an exam and to revise for an exam (Chester et al., 2011; Copley, 2007; Gosper et al., 2007; Laing \& Wootton, 2007; Williams \& Fardon, 2007).

The Technology Acceptance Model (TAM) introduced in the next chapter is used by the majority of correlation revealing studies.

\section{Factors Influencing Video Usage - Technology Acceptance Model}

The most widely-used model for the explanation of students' technology use is the Technology Acceptance Model (TAM) associated with the name of Fred Davis (1986).

According to the original model, the user attitude has a direct influence on the usage of a new information system, the aim of which is to measure the acceptance on the part of the system user. This attitude toward using is determined by another two variables: perceived usefulness and perceived ease of use. Perceived ease of use, beside its effect on attitude, has a direct effect on perceived usefulness as well. The relationships between TAM-constructs are shown in Figure 1. 


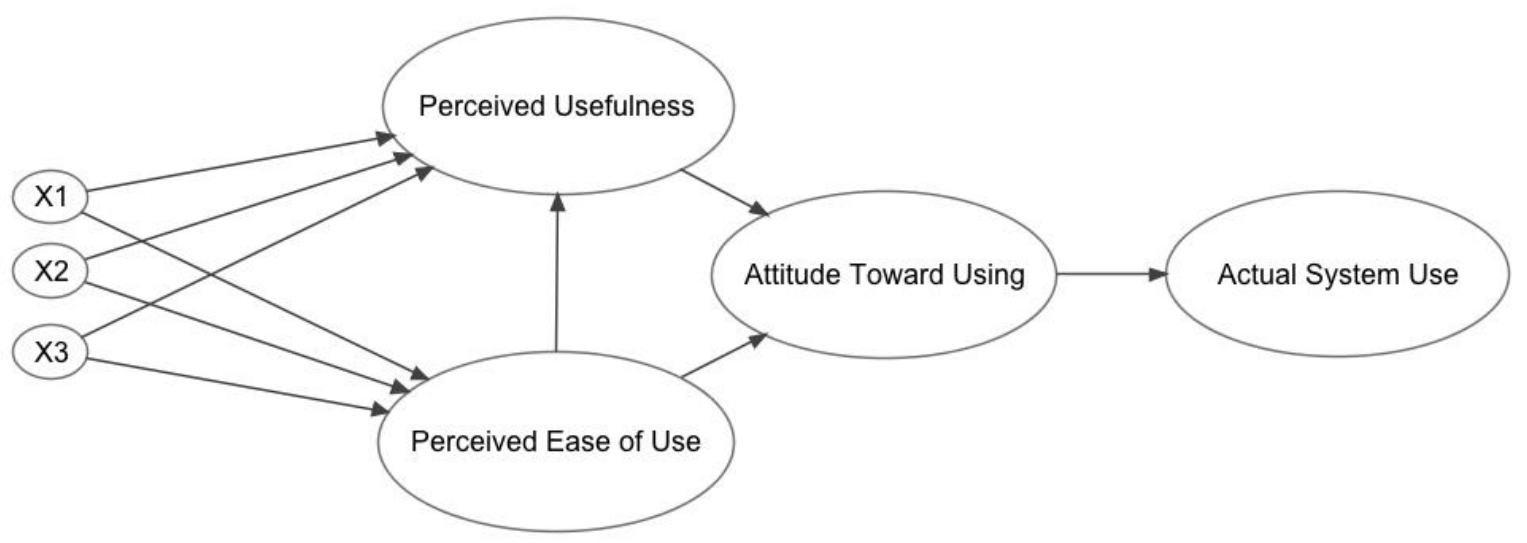

Figure 1. Correlation of original TAM factors. Reprinted from A technology acceptance model for empirically testing new end-user information systems: Theory and results (Doctoral dissertation), by Davis, 1986, Cambridge, MA: Sloan School of Management, Massachusetts Institute of Technology. Copyright 1986 by the Massachusetts Institute of Technology.

Both perceived usefulness and perceived ease of use have a direct effect on system use (Davis, Bagozzi, \& Warshaw, 1989; Sumak, Hericko, \& Pusnik, 2011; Venkatesh \& Davis, 2000). The above-mentioned correlations of constructs and their role in the explanation of behaviour, have been confirmed in several further studies carried out on different samples in different settings. For example, Sumak et al. (2011) in their meta-analysis enlist only educational applications, which evaluate e-learning systems, environments, or technologies and tools. They come to the conclusion that the results are consistent.

In higher education, the TAM model is used mainly for learning management systems. The Moodle system analysis is the most frequent, to which several extended models have been worked out. In the course of extension, numerous external variables that fit into the given educational environment are used. The variables measure the caracteristic features of the system such as perceived convenience (Hsu \& Chang, 2013), lack of LMS availability (Alharbi \& Drew, 2014), and technical support (Sanchez \& Hueros, 2010), or they measure the users' caracteristics and previous experience such as perceived playfulness (Padilla-Meléndez, Aguila-Obra, Garrido-Moreno, 2013); faculty type, academic year, GPA, skills on computer and internet, difficulty reading from computer screen, the number of previously elearning courses (Majdalawi, Almarabeh, \& Mohammad, 2014; Al-Assaf, Almarabeh, \& Eddin, 2015), LMS usage experience (Alharbi \& Drew, 2014), and computer self-efficacy (Sanchez \& Hueros, 2010).

Not only external variables can be used for the extension of the TAM model. In the article written by Islam (2013), three outcome constructs (namely perceived learning assistance, perceived community building assistance, and perceived academic performance) are involved in the TAM model revealing the possible outcomes of the Moodle e-learning systems adoption and the use among university students.

Relatively few studies based on the TAM model with the aim of examining video technology acceptance are available. Using the TAM constructions Donkor (2011) estimated the students' acceptance satisfaction regarding video lessons used among students of distance education. Lee and Lehto (2013) identified the determinants of the YouTube behavioural intention with their model in the course of their study into procedural learning through YouTube in a lab setting. For this they used an extension of the TAM model where they took the user satisfaction mediator variable and YouTube self-efficacy, 
vividness, content richness, task technology fit external variables into consideration beside the usual variables.

Based on the above-mentioned results, the following hypotheses have been set up in this research:

H1: Perceived ease of use has a significant positive effect on perceived usefulness.

H2: Perceived ease of use has a significant positive effect on attitude.

H3: Perceived usefulness has a significant positive effect on attitude.

H4: Attitude has a significant positive effect on video usage.

$\mathrm{H}_{5}$ : Perceived usefulness has a significant positive effect on video usage.

H6: Perceived ease of use has a significant positive effect on video usage.

Furthermore, it was assumed that, based on the findings of DeLone and McLean (2003) and Islam (2013) a correlation between video usage and learning performance can be hypothesized, namely:

H7: Video usage has a significant positive effect on learning performance.

According to the claim of Davis and his collegaues (Davis et al., 1989; Venkatesh \& Davis, 1996) when using the TAM it is important to take into consideration the external factors influencing perceived usefulness and perceived ease of use.

Including these factors in the study, special information can be obtained, apart from general correlations. Moreover, with their help, the explanatory power can be increased (Davis et al., 1989; Mathieson, 1991).

According to Abdullah and Ward's (2016) meta-analysis, self-efficacy is the most commonly used external factor in applications of the TAM in education. Self-efficacy is defined by Bandura (1997) as the belief "in one's capabilities to organize and execute the courses of action required to produce different attainments" (p. 3).

In the course of web-based learning, the student's self-efficacy can be interpreted as the ability to fulfil learning tasks with the help of the e-learning system or technology under consideration (Abbad, 2010). In such contexts e-learning, computer, and internet self-efficacy can be defined. The role of such selfefficacy constructs in defining the student's behaviour has been confirmed by several researchers through their direct influence on both perceived ease of use (Lee, Hsiao, \& Purnomo, 2014; Liang \& Tsai, 2008; Roca, Chiu, \& Martinez, 2006) and perceived usefulness (Lee et al., 2014; Rezaei, Mohammadi, Asadi, \& Kalanta, 2008).

Those students who have a higher level of self-efficacy for example in operating an e-learning system have a more positive perception of the ease of use of the given system and its usefulness and they are more willing to accept and use the system than their fellow-students who have a lower level of selfefficacy (Abbad, 2010). 
In this study the role of students' internet self-efficacy is examined with regard to two hypotheses.

H8: Internet self-efficacy has a significant positive effect on perceived ease of use.

H9: Internet self-efficacy has a significant positive effect on perceived usefulness.

\section{Factors Influencing Learning Satisfaction}

Satisfaction in general is the feeling of difference between prior expectations and perceived achievement. Keller (1983) defines learning satisfaction as a student's overall positive assessment of his or her learning experience. Satisfaction can be measured only after the learning activity.

In the case of learning using e-learning systems or technology, the most important factors, which have a positive effect on learning satisfaction, are the learner's actual performance (Hui, Hu, Clark, Tam, \& Milton, 2008; Liao, Palvia, \& Chen, 2009) and perceived usefulness, perceived ease of use and attitude, which are also connected to the given e-learning system or technology, measurable also after the learning activity (Del Barrio, Romero-Frías, \& Arquero, 2013; Hui et al., 2008; Lee \& Lehto, 2013; Sun, Tsai, Finger, Chen, \& Yeh, 2008). All of these are measurable only following the learning activity.

Consequently, with regard to video-based learning satisfaction, the following hypotheses were formulated:

H10: Learning performance has a significant positive effect on learning satisfaction.

H11: Perceived usefulness has a significant positive effect on learning satisfaction.

H12: Perceived ease of use has a significant positive effect on learning satisfaction.

H13: Attitude has a significant positive effect on learning satisfaction.

A further factor, identified by several researchers, (Abdous \& Yen, 2010; Ali \& Ahmad, 2011; Bray, Aoki, \& Dlugosh, 2008; Lee, 2012; Sahin, 2007; Yukselturk \& Yildirim, 2008) is interaction which is an important predictor of learning satisfaction in the course of web-based learning. Interaction is defined as verbal and non-verbal communication between players (Laurel, 1993). There are several types of interaction groupings, which are based on the type of players in them. The most widely-used system was developed by Moore (1989) for distance education and it contains three types of interaction groups: learner-teacher interaction, learner-learner interaction, and learner-content interaction.

In the course of web-based learning, students can exploit several interaction tools, for example instant message, e-mail, forum, discussion board, voice call, video call, voice conferencing, and video conferencing; all of which support interaction with other students and the teacher. Some of these tools can be found intergrated into e-learning systems, like Moodle.

If we examine the role of learner-teacher interaction and the role of learner-learner interaction in learning satisfaction separately, the results will be different. Some researchers claim that learnerteacher interaction has the greatest impact on learning satisfaction (Kuo, Walker, \& Schroder, 2010; Kuo, Walker, Schroder, \& Belland, 2014; Marks, Sibley, \& Arbaugh, 2005; Sahin, 2007) others, 
however, confirmed that learner-learner interaction has a greater effect on learning satisfaction (Jung et al., 2002; Rodriguez Robles, 2006).

The difference in findings can have several explanations. One of them is that different educational settings, such as different course requirements, need interactions of different levels (Kuo et al., 2010); the other is that interactive preferences may change depending on the type of student (Croxton, 2014).

Based on the results of previous research, it is assumed in this study that interaction has a positive effect on satisfaction. From this it was hypothesized:

H14: Learner-teacher interaction has a significant positive effect on learning satisfaction.

H15: Learner-learner interaction has a significant positive effect on learning satisfaction.

\section{Research Model}

Based on the findings of previous research, we created a research model for the examination of hypotheses, shown in Figure 2. In this model video usage and video-based learning satisfaction are used as dependent variables.

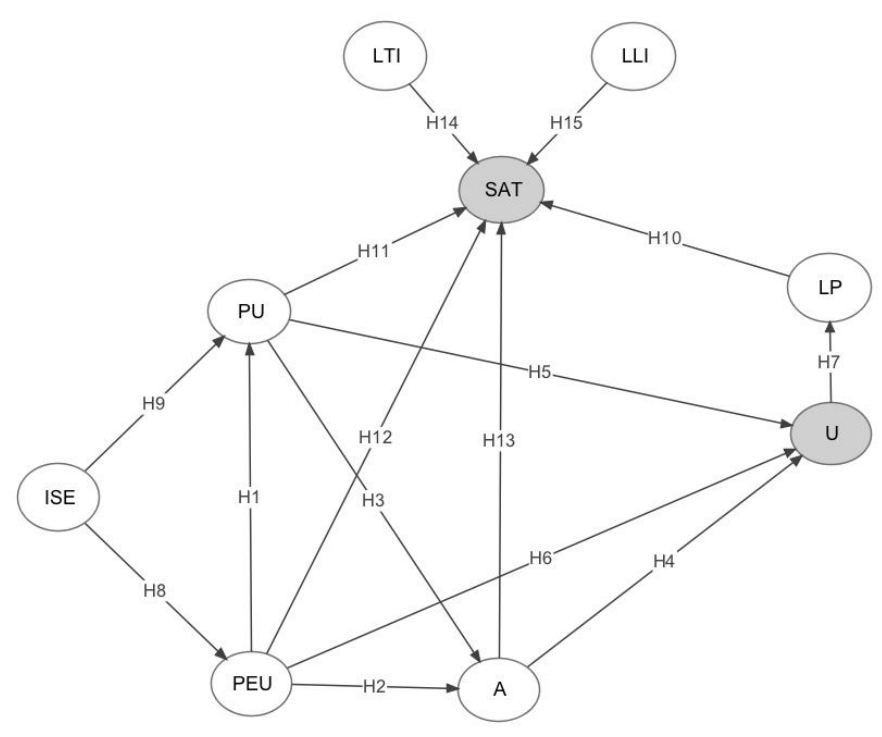

Figure 2. Research model.

${ }^{*}$ Note. $\mathrm{PU}=$ perceived usefulness; $\mathrm{PEU}=$ perceived ease of use; $\mathrm{A}=$ attitude; $\mathrm{SAT}=$ learning satisfaction; ISE = internet self-efficacy; LLI = learner-learner interaction; LTI = learner-teacher interaction; $\mathrm{U}=$ video usage; $\mathrm{LP}=$ learning performance

The definitions of the constructs used in the present research is summarized in Table 1. 
Table 1

Construct Definitions

\begin{tabular}{|c|c|c|}
\hline Construct & Definition & Source \\
\hline PU & $\begin{array}{l}\text { Perceived usefulness is defined as the degree to which } \\
\text { the user thinks that using the video will enhance his or } \\
\text { her performance. }\end{array}$ & (Davis, 1989) \\
\hline PEU & $\begin{array}{l}\text { Perceived ease of use is defined as the degree to which } \\
\text { the user thinks that using the video will be free from } \\
\text { effort. }\end{array}$ & (Davis, 1989) \\
\hline A & $\begin{array}{l}\text { Attitude towards using videos refers to the student's } \\
\text { positive or negative feelings associated with video-based } \\
\text { learning. }\end{array}$ & $\begin{array}{l}\text { (Fishbein \& Ajzen, } \\
\text { 1975, as cited in Davis } \\
\text { et al., 1989) }\end{array}$ \\
\hline SAT & $\begin{array}{l}\text { Learning satisfaction refers to the student's positive } \\
\text { feelings toward video-based learning experience. }\end{array}$ & (Keller, 1983) \\
\hline $\mathrm{U}$ & $\begin{array}{l}\text { Video usage is defined as the overall amount of video } \\
\text { usage estimated by the user. }\end{array}$ & $\begin{array}{l}\text { (Sun, Bhattacherjee, } \\
\& \text { Ma, 2009) }\end{array}$ \\
\hline ISE & $\begin{array}{l}\text { Internet self-efficacy refers to the student's belief in his } \\
\text { or her capabilities to organize and carry out internet } \\
\text { activities, to achieve the desired learning performance. }\end{array}$ & $\begin{array}{l}\text { (Eastin \& LaRose, } \\
\text { 2000) }\end{array}$ \\
\hline LLI & $\begin{array}{l}\text { Learner-learner interaction is a two-way mutual } \\
\text { communication between students who exchange } \\
\text { information, knowledge, thoughts and ideas. }\end{array}$ & $\begin{array}{l}\text { (Moore \& Kearsley, } \\
\text { 1996, as cited in Kuo } \\
\text { et al., 2014) }\end{array}$ \\
\hline LTI & $\begin{array}{l}\text { Learner-teacher interaction is a two-way } \\
\text { communication between the course teacher and the } \\
\text { students. }\end{array}$ & $\begin{array}{l}\text { (Moore \& Kearsley, } \\
\text { 1996, as cited in Kuo } \\
\text { et al., 2014) }\end{array}$ \\
\hline LP & $\begin{array}{l}\text { Learning performance is the student's result at the end } \\
\text { of the surveyed course. }\end{array}$ & \\
\hline
\end{tabular}

\section{Method}

\section{Questionnaire Development, Content Validity}

For the collection of demographic and educational data multiple choice questions were used (4 items), out of which there were one numerical and three nominal-level variables (Table 2).

To ensure content validity, the measurement of the latent variables in the model under study was carried out using a reduced version of the scale employed in other research ( 26 items). As a result, for the measurement of the constructs, widely-used scales or their simplified variants were used. Some minor changes were made to the formulation so that the items fit into the inter-relation of the research (Appendix 1).

\section{The Population Under Examination}

One hundred and five students of Edutus College in Hungary registered for Business Mathematics between the Spring semester of the academic year 2013/2014 and the Spring semester of the academic 
year 2014/2015. During the course, in addition to traditional classroom teaching, e-textbooks, and practicing exercises, the students had free access to online videos integrated into a Moodle environment. The usage of online videos was optional. The students themselves were allowed to decide to what extent they wanted to use the videos and to what extent they wanted to attend the face-to-face lessons. The students of the college have prior experience of online videos because in certain face-toface lectures video recordings are made, which are accessible after recording without being edited.

The Moodle course contained 13 lessons in all. Every lesson started with a short textual introduction followed by one (occasionally more) videos thus the students had access to 18 videos in total. The average length of the videos was 8.99 minutes (with a variance of 3.51 minutes). The videos, recorded in advance, were problem-based, demonstrating the step-by-step solution of a certain task in a splitscreen style. The videos were embedded in in the Moodle course with the help of Eduplayer module in a playable but not downloadable form. For playing the videos, the use of the browser was enough.

The Moodle course served as a communication channel between the teacher and the students and between students and students (message, forum, chat). It also served as an information surface for the students. The students could check information about the course (for example, course content or attendance sheets), about the schedule of the semester (for example, course content devided into weeks or dates of exams), about technical information about the course (for example, the need of software or settings), about the points collected during the semester, and the end of term grades.

With the aim of motivation, the teacher regularly sent an email message to the students informing them about the course content delivered in the latest face-to-face lesson, where it can be found in the Moodle course, and the teacher's suggestions regarding the videos to be watched and the tasks to be completed at home.

The students' interactions were not expected (either with the teacher or with each other). The channels merely offered a possibility to discuss any problem regarding the course content and the technical aspects of the course.

\section{Data Collection}

Data collection was carried out in writing. The online questionnaire was compiled with the help of Google Survey. Questionnaires were sent out by e-mail to 105 students at the end of the academic year 2014/2015, on May 7th, 2015. The questionnaire was available until September 2015. A total of 89 students responded and there were no invalid responses; thus the sample size of 89 was adequate for evaluating the research model. The demographic information about the respondents is given in Table 2. 
Table 2

Demographic Information

\begin{tabular}{llcc}
\hline & & Frequency & $\begin{array}{c}\text { Relative } \\
\text { frequency }\end{array}$ \\
\hline Gender & Female & 55 & 61.8 \\
& Male & 34 & 31.2 \\
Course & Daytime & 66 & 74.2 \\
& Correspondence & 23 & 25.8 \\
\multirow{3}{*}{ Field of study } & Business and Management & 15 & 16.9 \\
& Trade and Marketing & 44 & 49.4 \\
& International Business & 17 & 19.1 \\
& Tourism and Catering & 13 & 14.6 \\
Age & & Avg $=26.85$ & $\mathrm{SD}=4.63$ \\
\hline
\end{tabular}

\section{Data Analysis}

To evaluate the research model and to examine the hypotheses, structural equation modelling (SEM) using partial least squares (PLS) regression was used. The use of PLS path analysis (PLS-SEM) was justified by the low sample size $(\mathrm{N}=89)$ of the survey (Henseler, Ringle, \& Sinkovics, 2009) as well as the fact that normality was not confirmed in every construct (Chin, 1998).

The analysis was carried out using the SmartPLS 3 program (Ringle, Wende, \& Will, 2005). The model allows the simultaneous set up of factor analysis and path analysis. The results of factor analysis were used to examine the reliability and validity of the measurement model. The fit of the structural model was tested with t-tests and the help of bootstrapping (generating 5000 sub-samples and applying individual sign changes).

For the examination of construct reliability the Cronbach's alpha measurement of inner consistency with 0.7 limit was used as well as composite reliability (CR) also with 0.7 limit (Fornell \& Larcker, 1981; Hair, Black, Babin, \& Anderson, 2010). Table 3 shows that in the case of all constructs, both conditions are fulfilled and the scales are reliable. 
Table 3

The Characteristics of Constructs and Indicators

\begin{tabular}{|c|c|c|c|c|c|}
\hline Constructs & $\alpha$ & Items & $\begin{array}{l}\text { Standardized } \\
\text { factor } \\
\text { loadings }\end{array}$ & $\mathrm{CR}$ & AVE \\
\hline \multirow[t]{3}{*}{$\mathrm{PU}$} & 0.758 & PU1 & 0.756 & 0.862 & 0.676 \\
\hline & & PU2 & 0.798 & & \\
\hline & & $\mathrm{PU}_{3}$ & 0.906 & & \\
\hline \multirow[t]{3}{*}{ PEU } & 0.713 & PEU1 & 0.838 & 0.839 & 0.636 \\
\hline & & PEU2 & 0.691 & & \\
\hline & & PEU3 & 0.853 & & \\
\hline \multirow[t]{3}{*}{ A } & 0.803 & A1 & 0.788 & 0.885 & 0.720 \\
\hline & & A2 & 0.823 & & \\
\hline & & A3 & 0.929 & & \\
\hline \multirow[t]{4}{*}{ SAT } & 0.823 & SAT1 & 0.819 & 0.883 & 0.661 \\
\hline & & SAT2 & 0.915 & & \\
\hline & & $\mathrm{SAT}_{3}$ & 0.900 & & \\
\hline & & $\mathrm{SAT}_{4}$ & 0.570 & & \\
\hline \multirow[t]{4}{*}{ ISE } & 0.712 & ISE1 & 0.810 & 0.818 & 0.535 \\
\hline & & ISE2 & 0.859 & & \\
\hline & & ISE3 & 0.587 & & \\
\hline & & ISE4 & 0.633 & & \\
\hline \multirow[t]{3}{*}{ LLI } & 0.797 & LLI1 & 0.818 & 0.878 & 0.705 \\
\hline & & LLI2 & 0.848 & & \\
\hline & & LLI3 & 0.853 & & \\
\hline \multirow[t]{4}{*}{ LTI } & 0.780 & LTI1 & 0.726 & 0.856 & 0.599 \\
\hline & & LTI2 & 0.861 & & \\
\hline & & $\mathrm{LTI}_{3}$ & 0.688 & & \\
\hline & & $\mathrm{LTI}_{4}$ & 0.810 & & \\
\hline $\mathrm{U}$ & 1.000 & $\mathrm{U}$ & 1.000 & 1.000 & 1.000 \\
\hline LP & 1.000 & LP & 1.000 & 1.000 & 1.000 \\
\hline
\end{tabular}

${ }^{*}$ Note.

1. $\mathrm{PU}=$ perceived usefulness; $\mathrm{PEU}=$ perceived ease of use; $\mathrm{A}$ = attitude; SAT = learning satisfaction; ISE $=$ internet selfefficacy; LLI = learner-learner interaction; LTI = learnerteacher interaction; $\mathrm{U}=$ video usage; $\mathrm{LP}=$ learning performance

2. $\alpha=$ Cronbach's alpha; $\mathrm{CR}=$ composite reliability; $\mathrm{AVE}=$ average variance extracted.

Based on the classification of Henseler et al. (2009), content validity, convergent validity, and discriminant validity are examined in this study. Content validity was guaranteed in this research by taking the indicators from previous research in the field of education as mentioned earlier. The assessment of convergent validity was carried out with the help of average variance extracted (AVE) based on the 0.5 criterion value, suggested by (Fornell \& Larcker, 1981). Table 3 shows that the AVE value of each construct is above 0.5 , thus the condition of convergent validity are fulfilled. Discriminant validity was proved in this study with the help of correlation matrix and the AVE values (Table 4) based on Fornell and Larcker (1981) criterion. Since, in the case of all variables, the square root of AVE values is greater than the off-diagonal values, discriminant validity between variables is satisfactory (Fornell \& Larcker, 1981). 
Table 4

Construct Correlations and the Square Root of AVE Values

\begin{tabular}{|c|c|c|c|c|c|c|c|c|c|}
\hline Construct & PU & PEU & A & SAT & ISE & LLI & LTI & $\mathrm{U}$ & LP \\
\hline Perceived usefulness (PU) & $\begin{array}{r}0.8 \\
22\end{array}$ & & & & & & & & \\
\hline Perceived ease of use (PEU) & $\begin{array}{r}0.61 \\
8\end{array}$ & $\begin{array}{r}0.79 \\
8\end{array}$ & & & & & & & \\
\hline Attitude (A) & $\begin{array}{r}0.59 \\
2\end{array}$ & $\begin{array}{r}0.70 \\
4\end{array}$ & $\begin{array}{r}0.8 \\
48\end{array}$ & & & & & & \\
\hline Learning satisfaction (SAT) & $\begin{array}{r}0.51 \\
7\end{array}$ & $\begin{array}{r}0.58 \\
7\end{array}$ & $\begin{array}{r}0.55 \\
8\end{array}$ & $\begin{array}{r}\mathbf{0 . 8 1} \\
3\end{array}$ & & & & & \\
\hline Internet self-efficacy (ISE) & $\begin{array}{r}0.48 \\
0\end{array}$ & $\begin{array}{r}0.53 \\
1\end{array}$ & $\begin{array}{r}0.45 \\
6\end{array}$ & $\begin{array}{r}0.26 \\
6\end{array}$ & 0.731 & & & & \\
\hline $\begin{array}{l}\text { Learner-learner interaction } \\
\text { (LLI) }\end{array}$ & $\begin{array}{r}0.39 \\
2\end{array}$ & $\begin{array}{r}0.41 \\
2\end{array}$ & $\begin{array}{r}0.35 \\
3\end{array}$ & $\begin{array}{r}0.53 \\
9\end{array}$ & 0.063 & $\begin{array}{r}0.8 \\
40\end{array}$ & & & \\
\hline $\begin{array}{l}\text { Learner-teacher interaction } \\
\text { (LTI) }\end{array}$ & $\begin{array}{r}0.41 \\
9\end{array}$ & $\begin{array}{r}0.32 \\
1\end{array}$ & $\begin{array}{r}0.33 \\
5\end{array}$ & $\begin{array}{r}0.69 \\
3\end{array}$ & 0.202 & $\begin{array}{r}0.49 \\
4\end{array}$ & $\begin{array}{r}0.77 \\
4\end{array}$ & & \\
\hline Video usage (U) & $\begin{array}{r}0.56 \\
2\end{array}$ & $\begin{array}{r}0.55 \\
0\end{array}$ & $\begin{array}{r}0.65 \\
0\end{array}$ & $\begin{array}{r}0.44 \\
0\end{array}$ & 0.446 & $\begin{array}{r}0.33 \\
6\end{array}$ & $\begin{array}{r}0.25 \\
1\end{array}$ & $\begin{array}{r}1.00 \\
0\end{array}$ & \\
\hline Learning performance (LP) & $\begin{array}{r}0.06 \\
2\end{array}$ & $\begin{array}{r}0.12 \\
7\end{array}$ & $\begin{array}{r}0.22 \\
6\end{array}$ & $\begin{array}{r}0.35 \\
9\end{array}$ & -0.081 & $\begin{array}{r}0.22 \\
8\end{array}$ & $\begin{array}{r}0.12 \\
5\end{array}$ & $\begin{array}{r}0.25 \\
0\end{array}$ & $\begin{array}{r}1.00 \\
\mathbf{0}\end{array}$ \\
\hline
\end{tabular}

*Note. In the correlation matrix the square root of average variance extracted (AVE) values presented diagonally.

\section{Results and Discussion}

The model obtained as a result of the PLS path analysis is shown in Figure 3, on which are displayed the path coefficients, their significance tests (the bootstrapping results) and the multiple determination coefficients $\left(\mathrm{R}^{2}\right)$. 


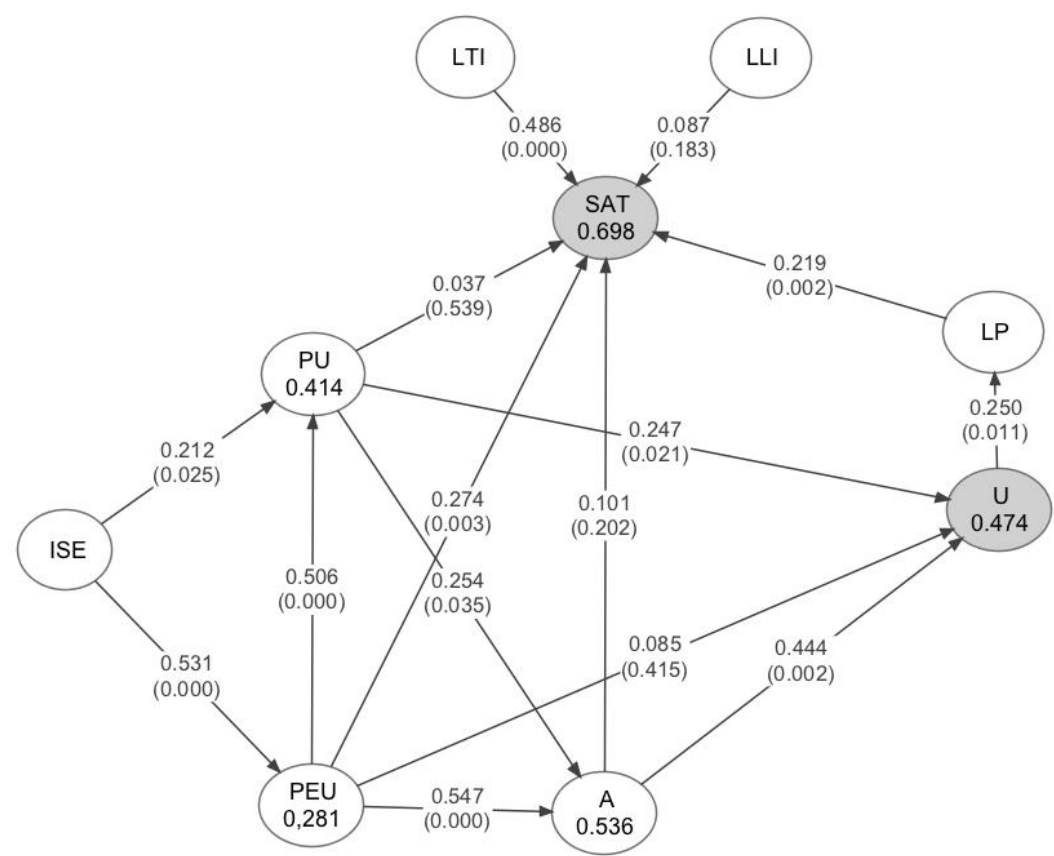

Figure 3. The results of partial least squares regression.

*Notes. 1. The explained variance (R2) is shown in the circles, path coefficient on arrows, bootstrap results in brackets. 2. $\mathrm{PU}=$ perceived usefulness; $\mathrm{PEU}=$ perceived ease of use; $\mathrm{A}=$ attitude; $\mathrm{SAT}=$ learning satisfaction; ISE = internet self-efficacy; LLI = learner-learner interaction; LTI = learner-teacher interaction; $\mathrm{U}=$ video usage; LP = learning performance

In hypotheses $\mathrm{H} 1-\mathrm{H} 6$, the core TAM constructs influencing video usage are perceived usefulness, perceived ease of use, and attitude. The inter-relation of perceived usefulness, perceived ease of use, and attitude was also hypothesized. The results confirmed the significant positive effect of perceived usefulness $\left(\mathrm{H}_{5}, \beta=0.247 ; \mathrm{p}=0.021\right)$ and the significant positive effect of attitude $\left(\mathrm{H}_{4}, \beta=0.444\right.$; $\mathrm{p}=0.002$ ) on video usage.

The direct effect of perceived ease of use on video usage was not significant (H6, $\beta=0.085 ; p=0.415)$. It is characteristic of such models in which measurement was taken after usage and not before it (van Raaij \& Schepers, 2008; Venkatesh, Morris, Davis, \& Davis, 2003).

Further direct interactions between TAM-variables in accordance with other TAM results all proved significant. Pereceived ease of use has a direct positive effect on perceived usefulness ( $\mathrm{H} 1, \beta=0.506$; $\mathrm{p}<0.001)$, perceived ease of use has a direct positive effect on attitude (H2, $\beta=0.547 ; p<0.001)$, and perceived usefulness has a direct positive effect on attitude $\left(\mathrm{H}_{3}, \beta=0.254 ; \mathrm{p}=0.035\right)$.

Based on the above-mentioned results hypotheses $\mathrm{H}_{1}-\mathrm{H}_{5}$ have been accepted, hypothesis $\mathrm{H} 6$, however, has been rejected.

The model role of internet self-efficacy was formulated in the form of two hypotheses. The results harmonize with those of other researchers (Lee et al., 2014; Liang \& Tsai, 2008; Rezaei et al., 2008; 
Roca et al., 2006) according to which internet self-efficacy has a direct significant positive effect on perceived ease of use $(\mathrm{H} 8, \beta=0.531 ; \mathrm{p}<0.001)$ as well as on perceived usefulness $(\mathrm{H} 9, \beta=0.212$; $\mathrm{p}=0.025$ ). Based on this, hypotheses H8-H9 were accepted. From the results it can be concluded that internet self-efficacy has a significant indirect effect on students' attitude $(0.412 ; \mathrm{p}<0.001)$ and on video usage (o.347; $\mathrm{p}<0.001)$ as well.

Using the extended TAM model mentioned above, $47.4 \%$ of video usage variance was successfully explained. This explanatory power of the extended TAM model is consistent with previous studies. It is considered that TAM consistently explains about $34 \%-52 \%$ of the variance in usage intentions (in case of a specific system) (Venkatesh \& Davis, 2000).

The relation of video usage and learning satisfaction was predicted through a mediator variable: namely learning performance. The findings supported the prediction that video usage has a direct, significant positive effect on learning performance $\left(\mathrm{H}_{7}, \beta=0.250 ; \mathrm{p}=0.011\right)$ and that learning performance has a direct positive effect on learning satisfaction (H10, $\beta=0.219 ; p=0.002)$. Furthermore, the research provided evidence that video usage also has an indirect positive effect on learning satisfaction (0.055; $\mathrm{p}=0.044)$.

From among further hypothesized explanatory variables (perceived ease of use, perceived usefulness, attitude, learner-teacher interaction, learner-learner interaction) learner-teacher interaction has a stronger positive direct effect $\left(\mathrm{H}_{14}, \beta=0.486 ; \mathrm{p}<0.001\right)$ on learning performance, while perceived ease of use has a weaker positive direct effect on it (H12, $\beta=0.247 ; \mathrm{p}=0.003)$. The direct positive effect of perceived usefulness (H11, $\beta=0.037 ; p=0.539)$, attitude (H13, $\beta=0.101 ; p=0.202)$, and learner-leanrer interaction $(\mathrm{H} 15, \beta=0.087 ; \mathrm{p}=0.183)$ was not significant.

With regard to learning satisfaction we succeeded in reaching a 69.8\% explained variance, with the help of the examined explanatory variables. In addition to this the model confirmed further important indirect connections, which were not predicted in the hypotheses.

Factors influencing video usage can have an indirect effect, both on learning performance and learning satisfaction. In the research we could also demonstrate that perceived ease of use $(0.128 ; \mathrm{p}=0.034)$ and perceived usefulness (0.090; $\mathrm{p}=0.034)$ have an indirect significant positive effect on learning performance. The effect of attitude on learning performance was not significant $(0.111 ; \mathrm{p}=0.066)$.

In accordance with earlier studies (Liu, 2008; Shi, Chen, \& Tian, 2011; Tsai \& Tsai, 2003; Kuo et al., 2014; Womble, 2007), this study confirms that internet self-efficacy has an indirect positive effect on learning performance $(0.087 ; \mathrm{p}=0030)$ and learning satisfaction $(0.233 ; \mathrm{p}=0.001)$.

The indirect effects between constructs as well as their significance are shown in Table 5 . 
Table 5

Indirect Effects Between Constructs

\begin{tabular}{lll} 
Relationships & Indirect effect & $p$ \\
\hline ISE-A & 0.412 & 0.000 \\
ISE-LP & 0.087 & 0.030 \\
ISE-SAT & 0.223 & 0.001 \\
ISE-U & 0.347 & 0.000 \\
PEU-LP & 0.128 & 0.034 \\
PU-LP & 0.090 & 0.034 \\
U-SAT & 0.055 & 0.044 \\
\hline
\end{tabular}

${ }^{*}$ Note. $\mathrm{PU}=$ perceived usefulness; $\mathrm{PEU}=$ perceived ease of use; A = attitude; SAT = learning satisfaction; ISE = internet self-efficacy; LLI = learner-learner interaction; LTI = learner-teacher interaction; $\mathrm{U}=$ video usage; LP = learning performance.

\section{Conclusion and Implications}

The TAM model was extended in the study with the aim of analysing the university students' video usage and the correlations of the factors influencing learning satisfaction relating to the usage. The model provides a useful theoretical basis for understanding the Edutus College students' video usage and learning satisfaction. The findings assist the college leadership and teachers in successful application of educational video.

Furthermore the model, which was validated in the college environment, ensures an integrated theoretical framework which can be used to estimate the university students' usage of video technology and the learning satisfaction connected with the usage, whether it be within the framework of traditional education or of distance learning.

The results of the study have several consequences for further research and practical application. The data to a certain extent support the existence of the basic TAM correlations in a Hungarian college of business studies, thus confirming the robustness and explanatory power of TAM for the use of technology in a higher education setting.

Perceived usefulness and attitude exert the strongest influence on video usage; therefore it is advisable to take measures that could reinforce the positive opinion of students' video usage.

Perceived ease of use did not have a significant direct effect on video usage. The logical explanation for this could be that video usage for educational purposes, accessible online, proves to be easy. Another reasonable explanation could be that students tend to overcome the difficulties of video usage to achieve better results in their studies.

Internet self-efficacy significantly influences video usage, learning performance, and learning satisfaction. It is therefore essential to assess self-efficacy and to use suitable methods for increasing the students' internet self-efficacy. They can be embedded in education if needed. 
Learner-teacher interaction had a significant effect on learning satisfaction, while the effect of learnerlearner interaction on learning satisfaction was not significant. The possible explanation of the latter correlation on the one hand is that in the type of course learner-learner interaction was not expected, in other words group work was not used. On the other hand the study did not take the quality of interactions and their goal into account. As a result we were not familiar with the type of interaction among students.

Learner-teacher interaction can be inspired via the teacher's intervention and initiative. It could equally be important to guarantee further possibilities for interaction in a Moodle environment, since the intensity of interaction can considerably be influenced by the quantity and quality of communication channels offered by LMS.

\section{Limitations and Future Work}

As in every study some limitations should be mentioned in this study as well, a part of which could inspire further research. Firstly, the restrictions are attributed to the application of self-admission measurement, as a result the data obtained were not objective for the examination of the model. Therefore, further research should be carried out in the future in which it would be advisable to combine the video usage data based on self-confession with the data of online students' activities derived from the diary file of the web server.

Secondly, since the research was carried out in a given course of a college, in a given education setting, we should be careful when generalizing the results. It is also advisable to use the model in the future for analysing further courses in other fields of science and offered by other universities.

Thirdly, every effort should be made to increase the explained variance: by increasing Cronbach's alpha, the number of items in each scale, then performing an item analysis to get the highest possible alpha; by increasing the sample size and by making sure that the sample is adequately homogeneous, for which the examination analysis of different individual factors (such as socio-economic background knowledge of ICT and motivational factors) as moderator variables is suggested, using multi-group analysis methods. 


\section{References}

Abdous, M., \& Yen, C.-J. (2010). A predictive study of learner satisfaction and outcomes in face-toface, satellite broadcast, and live video-streaming learning environments. Internet and Higher Education, 13, 248-257.

Abdullah, F., \& Ward, R. (2016). Developing a general extended technology acceptance model for elearning (GETAMEL) by analysing commonly used external factors. Computers in Human Behavior, 56, 238-256.

Abbad, M. (2010). Learning from group interviews: Exploring dimensions of learning management system acceptance. International Journal of Instructional Technology and Distance Learning, 7(3), 25-39.

Abbad, M., Morris, D., \& Nahlik, C. D. (2009). Looking under the bonnet: Factors affecting student adoption of E-learning systems in Jordan. International Review of Research in Open and Distance Learning, 1O(2), 1-25. Retrieved from https:// library3.hud.ac.uk/summon/

Al-Assaf, N., Almarabeh, T., \& Eddin, L. N. (2015). A study on the impact of learning management system on students of the University of Jordan. Journal of Software Engineering and Applications, 8, 590-601.

Al-Gahtani, S. S. (2016). Empirical investigation of e-learning acceptance and assimilation: A structural equation model. Applied Computing and Informatics, 12, 27-50.

Alharbi, S. \& Drew, S. (2014). Using the technology acceptance model in understanding academics' behavioural intention to use learning management systems. International Journal of Advanced Computer Science and Applications, 5(1), 143-155.

Ali, A., \& Ahmad, I. (2011). Key factors for determining students' satisfaction in distance learning courses: A study of Allama Iqbal Open University. Contemporary Educational Technology, 2(2), 118-134.

Bandura, A. (1997). Self-Efficacy: The exercise of control. New York, NY: Freeman.

Bray, E., Aoki, K., \& Dlugosh, L. (2008). Predictors of learning satisfaction in Japanese online distance learners. International Review of Research in Open \& Distributed Learning, 9(3), 124.

Chester, A. Buntine A., Hammond, K., \& Atkinson, L. (2011). Podcasting in education: Student attitudes, behaviour and self-efficacy. Educational Technology \& Society, 14(2), 236-247.

Chin, W. (1998). Issues and opinion on structural equation modeling. MIS Quarterly, 22(1), 7-16.

Choi, H. J., \& Johnson, S. D. (2007). The effect of problem-based video instruction on learner satisfaction, comprehension and retention in college courses. British Journal of Education Techology, 38(5), 885-895. 
Copley, J. (2007). Audio and video podcasts of lectures for campus-based students: Production and evaluation of student use. Innovations in Education and Teaching International, 44(4), 387399.

Croxton, R. (2014). The role of interactivity in student satisfaction and persistence in online learning. MERLOT Journal of Online Learning and Teaching, 1O(2), 314-325.

Dalal, M. (2014). Pilot impact of multi-media tutorials in a computer science laboratory course - An empirical study. The Electronic Journal of e-Learning, 12(4), 366-374.

Davis, F. D. (1986). A technology acceptance model for empirically testing new end-user information systems: Theory and results (Doctoral dissertation), Cambridge, MA: Sloan School of Management, Massachusetts Institute of Technology.

Davis, F. D. (1989). Perceived usefulness, perceived ease of use, and user acceptance of information technology. MIS quarterly, 13(3), 319-340.

Davis, F., Bagozzi, R., \& Warshaw, P. (1989). User acceptance of computer technology: A comparison of two theoretical models. Management Science, 35(8), 982-1003.

Day, J., \& Foley, J. (2006). Evaluating web lectures: A case study from HCI. Paper presented at the Conference on Human Factors in Computing Systems (CHI EA '06), Montreal, Canada.

Del Barrio, S., Romero-Frías, E., \& Arquero, J. (2013). The role of e-learning satisfaction in the acceptance of technology for educational purposes: a competing models analysis. Proceedings of The Open and Flexible Higher Education Conference 2013, EADTU (pp. 36-49). Paris, France: European Association of Distance Teaching Universities.

DeLone, W., \& McLean, E. (2003). The DeLone and McLean model of information systems success: A ten year update. Journal of Management Information Systems, 19(4), 9-30.

DeVaney, T. A. (2009). Impact of video tutorials in an online educational statistics course. MERLOT Journal of Online Learning and Teaching, 5(4), 600-608.

Donkor, F. (2010). The comparative instructional effectiveness of print-based and video-based instructional materials for teaching practical skills at a distance. The International Journal Review of Research in Open and Distance Learning, 11(1), 96-116. Retrieved from http://www.irrodl.org/index.php/irrodl/article/view/792/1506

Donkor, F. (2011). Assessment of learner acceptance and satisfaction with video-based instructional materials for teaching practical skills at a distance. The International Review of Research in Open and Distributed Learning, 12(5), 74-92. Retrieved from http://www.irrodl.org/index.php/irrodl/article/view/953/1891

Dupagne, M., Millette, D. M., \& Grinfeder, K. (2009). Effectiveness of video podcast use as a revision tool. Journalism \& Mass Communication Educator, 64(1), 54-70. 
Dupuis, J., Coutu, J., \& Laneuville, O. (2013). Application of linear mixed-effect models for the analysis of exam scores: Online video associated with higher scores for undergraduate students with lower grades. Computers \& Education, 66, 64-73.

Eastin, M., \& LaRose, R. (2000). Internet self-efficacy and the psychology of the digital divide. Journal of Computer-Mediated Communication, 6(1). Retrieved from http://jcmc.indiana.edu/vol6/issue1/eastin.html

Evans, C. (2008). The effectiveness of m-learning in the form of podcast revision lectures in higher education. Computers \& Education, 5o(2), 491-498.

El-Sayed, R., E. \& El-Sayed, S. E. A. E. (2013). Video-based lectures: An emerging paradigm for teaching human anatomy and physiology to student nurses. Alexandria Journal of Medicine, 49, 215-222.

Figlio, D., Rush, M., \& Yin, L. (2010). Is it live or is it Internet? Experimental estimates of the effects of online instruction on student learning (Working Paper No. 16089). Retrieved from http://www.nber.org/papers/w16089

Fornell, C., \& Larcker, F. (1981). Evaluating structural equation models with unobservable variables and measurement error. Journal of Marketing Research, 18(1), 39-50.

Giannakos, M. N., Chorianopoulos, K., \& Chrisochoides, N. (2015). Making sense of video analytics: Lessons learned from clickstream interactions, attitudes, and learning outcome in a videoassisted course. International Review of Research in Open and Distance Learning, 16(1). Retrieved from http://www.irrodl.org/index.php/irrodl/article/view/1976/3198

Gosper, M., McNeill, M.,Woo, K., Phillips, R., Preston, G., \& Green, D. (2007). Web-based lecture recording technologies - Do students learn from them? Paper presented at EDUCAUSE Australasia. Melbourne, Australia.

Grandon, E., Alshare, O., \& Kwan, O. (2005). Factors influencing student intention to adopt online classes: A cross-cultural study. Journal of Computing Sciences in Colleges, 2O(4), 46-56.

Hair, J., Black, W., Babin, B., \& Anderson, R. (2010). Multivariate data analysis ( $7^{\text {th }}$ ed.). Upper Saddle River, NJ: Prentice Hall.

Henseler, J., Ringle, C., \& Sinkovics, R. (2009). The use of partial least squares path modeling in international marketing. Advences in International Marketing, 20, 277-319.

Hill, J. L., \& Nelson, A. (2011). New technology, new pedagogy? Employing video podcasts in learning and teaching about exotic ecosystems. Environmental Education Research, 17(3), 393-408.

Hsu, H. H., \& Chang, Y. Y. (2013). Extended TAM model: Impacts of convenience on acceptance and use of moodle. US-China Education Review, 3(4), 211-218. 
Hui, W., Hu, P., Clark, T., Tam, K., \& Milton, J. (2008). Technology-assisted learning: A longitudinal field study of knowledge category, learning effectiveness, and satisfaction in language learning. Journal of Computer Assisted Learning, 24(3), 245-259.

Islam, A. (2013). Investigating e-learning system usage outcomes in the university context. Computers \& Education, 69, 387-399.

Jung, I., Choi, S., Lim, C., \& Leem, J. (2002). Effects of different types of interaction on learning achievement, satisfaction and participation in web-based instruction. Innovations in Education and Teaching International, 39(2), 153-162.

Kay, R., \& Kletskin, I. (2012). Evaluating the use of problem-based video podcasts to teach mathematics in higher education. Computers \& Education, 59, 619-627.

Keller, J. (1983). Motivational design of instruction. In C. Reigeluth, (Ed.), Instructional design theories and models: An overview of their current status (pp. 386-434). Hillsdale, NJ: Erlbaum.

Kelly, M., Lyng, C., McGrath, M., \& Cannon, G. (2009). A multi-method study to determine the effectiveness of, and student attitudes to, online instructional videos for teaching clinical nursing skills. Nurse Education Today, 29(3), 292-300.

Kim, J., \& Chen, C.-Y. (2011). The influence of integrating pre-online lecture videos in classrooms: A case study. In Bonk, C. J., \& Ho, C. P. (Ed.) Proceedings of World Conference on E-Learning in Corporate, Government, Healthcare, and Higher Education (pp. 244-249). Chesapeake: VA: Association for the Advancement of Computing in Education.

King, W. R., \& He, J. (2006). A meta-analysis of the technology acceptance model. Information and Management, 43(6), 740-755.

Koohang, A., \& Durante, A. (2003). Learners' perceptions toward the web-based distance learning activities/assignments portion of an undergraduate hybrid instructional model. Journal of Informational Technology Education, 2, 105-113.

Kuo, Y., Walker, A., \& Schroder, K. (2010). Interaction and other variables as predictors of student satisfaction in online learning environment. Paper presented at the annual meeting of the Society for Information Technology \& Teacher Education (SITE). San Diego, California.

Kuo, Y.-C., Walker, A., Schroder, K., \& Belland, B. (2014). Interaction, internet self-efficacy, and selfregulated learning as predictors of student satisfaction in online education courses. The Internet and Higher Education, 2O, 35-50.Kurtz, B. L., Fenwick Jr., J. B., \& Ellsworth C. C. (2007). Using podcasts and tablet PCs in computer science. Proceedings of the 45th annual ACM Southeast regional conference (pp. 484-489). Winston-Salem, NC, USA: Association for Computing Machinery.

Laurel, B. (1993). Computer as theatre. New York, NY.: Addison-Wesley. 
Lee, J. (2012). Patterns of interaction and participation in a large online course: Strategies for fostering sustainable discussion. Educational Technology \& Society, 15(1), 260-272.

Lee, D., \& Lehto, M. (2013). User acceptance of YouTube for procedural learning: An extension of the Technology Acceptance Model. Computers \& Education, 193-208.Lee, Y.-H., Hsiao, C., \& Purnomo, S. (2014). An empirical examination of individual and system characteristics on enhancing e-learning acceptance. Australasian Journal of Educational Technology, 30(5), 561-579.

Liang, J., \& Tsai, C. (2008). Internet self-efficacy and preferences toward constructivist Internetbased learning environments: A study of pre-school teachers in Taiwan. Educational Technology \& Society, 11(1), 226-237.

Laing, C., \& Wootton, A. (2007). Using podcasts in higher education. Health Information on the Internet, 6o, 7-9.

Liao, C., Palvia, P., \& Chen, J.-L. (2009). Information technology adoption behavior life cycle: Toward a technology continuance theory (TCT). International Journal of Information Management, 29(4), 309-320.

Liu, S. (2008). Student interaction experiences in distance learning courses a phenomenological study. Online Journal of Distance Learning Administration, 11(1).

Lloyd, S. A., \& Robertson, C. L. (2012). Screencast tutorials enhance student learning of statistics. Teaching of Psychology, 39(1), 67-71.

Lonn, S. \& Teasley, S. D. (2009). Podcasting in higher education: What are the implications for teaching and learning? Internet and Higher Education, 12(2), 88-92.

Majdalawi, Y. Kh., Almarabeh, T., \& Mohammad, H. (2014). Factors affecting students' usage of learning management system at the University of Jordan. Life Science Journal, 11(6), 666671.

Mathieson, K. (1991). Predicting user intentions: Comparing the technology acceptance model with the theory of planned behavior. Information Systems Research, 2(3), 173-191.

Marks, R., Sibley, S., \& Arbaugh, J. (2005). A structural equation model of predictors for effective online learning. Journal of Management Education, 29, 531- 565.

McConville, S. A., \& Lane, A. M. (2006). Using on-line video clips to enhance self- efficacytoward dealing with difficult situations among nursing students. Nurse Education Today, 26(3), 200-208.

McElroy, J. \& Blount, Y. (2006). You, me and iLecture. In L. Markauskaite, P. Goodyear, \& Reimann (Eds.). Proceedings of the 23rd Annual Conference of the Australasian Society for Computers in Learning in Tertiary Education: Who's Learning? Whose Technology? (pp. 549-558). Sydney: Sydney University Press. 
Moore, M. (1989). Three types of interactions. The American Journal of Distance Education, 3(2), 16.

Noel-Levitz, R. (2011). National online learners priorities report (PDF). Retrieved from www.noellevitz.com/upload/Papers and Research/2011/PSOL report\%202011.pdf

Padilla-Meléndez, A., Aguila-Obra, A. R. D., \& Garrido-Moreno, A. (2013). Perceived playfulness, gender differences and technology acceptance model in a blended learning scenario. Computers \& Education, 63, 306-317.

Palmer, A., \& Koenig-Lewis, N. (2012). The effects of pre-enrolment emotions and peer group interaction on students' satisfaction. Journal of Marketing Management, 27, 1208-1231.

Rezaei, M., Mohammadi, H., Asadi, A., \& Kalanta, K. (2008). Predicting e-learning application in agricultural higher education using technology acceptance model. Turkish Online Journal of Distance Education-TOJDE, 98(1), 85-95.

Ringle, C., Wende, S., \& Will, A. (2005). Smartpls. Hamburg, Germany: University of Hamburg.

Roca, J., Chiu, C.-M., \& Martinez, F. (2006). Understanding e-learning continuance intention: an extension of the Technology Acceptance Model. International Journal of Human-Computer Studies, 64(8), 683-696.

Rodriguez Robles, F. M. (2006). Learner characteristic, interaction and support service variables as predictors of satisfaction in Web-based distance education. Dissertation Abstracts International, 67(07).

Sahin, I. (2007). Predicting student satisfaction in distance education and learning environments. Turkish Online Journal of Distance Education-TOJDE, 8(2), 113-119.

Sanchez, R. A. \& Hueros, A. D. (2010). Motivational factors that influence the acceptance of Moodle using TAM. Computers in Human Behavior, 26, 1632-1640.

Schepers, J., \& Wetzels, W. (2007). A meta-analysis of the technology acceptance model: Investigating subjective norm and moderation effects. Information \& Managment, 44(1), 90-103.

Shi, J., Chen, Z., \& Tian, M. (2011). Internet self-efficacy, the need for cognition, and sensation seeking as predictors of problematic use of the Internet. CyberPsychology, Behavior, and Social Networking, 14(4), 213-234.

Soong, S. K. A., Chan, L. K., Cheers, C., \& Hu., C. (2006). Impact of video recorded lectures among students. In L. Markauskaite, P. Goodyear, \& P. Reimann (Eds.) Proceedings of ASCILITE (pp. 789-793). Sydney, Australia.

Sun, P.-C., Tsai, R., Finger, G., Chen, Y.-Y., \& Yeh, D. (2008). What drives a successful e-learning? An empirical investigation of the critical factors influencing learner satisfaction. Computers \& Education, 5O(4), 1183-1202. 
Sun, Y., Bhattacherjee, A., \& Ma, W. (2009). Extending technology usage to work settings: The role of perceived work compatibility in ERP implementation. Information \& Management, 46(6), $351-356$.

Sumak, B., Hericko, M., \& Pusnik, M. (2011). A meta-analysis of e-learning technology acceptance: The role of user types and e-learning technology types. Computers in Human Behavior, 27, 2067-2077.

Traphagan, T., Kucsera, J., \& Kishi, K. (2010). Impact of class lecture webcasting on attendance and learning. Educational Technology Research \& Development, 58(1), 19-37.

Tsai, M.-J., \& Tsai, C.-C. (2003). Information searching strategies in web-based science learning: The role of internet self-efficacy. Innovations in Education and Teaching International, 4O(1), 43-50.

Vajoczk, S., Watt, S., Marquis, N., \& Holshausen, K. (2010). Podcasts: Are they an effective tool to enhance student learning? A case study. Journal of Educational Multimedia and Hypermedia, 19(3), 349-362.

van Raaij, E., \& Schepers, J. (2008). The acceptance and use of a virtual learning environment in China. Computers \& Education, 50, 838-852.

Venkatesh, V., \& Davis, F. (1996). A model of the antecedents of perceived ease of use: Development and test. Decision Sciences, 27, 451-481.

Venkatesh, V., \& Davis, F. (2000). A theoretical extension of the technology acceptance model: Four longitudinal field studies. Management Science, 46(2), 186-204.Venkatesh, V., Morris, M., Davis, G., \& Davis, F. (2003). User acceptance of information technology: Toward a unified view. MIS Quarterly, 27, 425-478.

Venkatesh, V., Thong, J. Y. L., \& Xu X. (2012). Consumer acceptance and use of information technology: extending the unified theory of acceptance and use of technology. MIS Quarterly. 36(1), 157-178.

Wieling, M., \& Hofman, W. (2010). The impact of online video lecture recordings and automated feedback on student performance. Computers \& Education, 54(4), 992-998.

Williams, A., Birch, E., \& Hancock, P. (2012). The impact of online lecture recordings on student performance. Australasian Journal of Educational Technology, 28(2), 199-213.

Williams, J., \& Fardon, M. (2007, September). Recording lectures and the impact on student attendance. Paper presented at the ALT-C, Nottingham, UK.

Womble, J. (2007). E-learning: The relationship among learner satisfaction, self-efficacy, and usefulness (Doctoral dissertation). San Diego: Alliant International University. 
Yukselturk, E., \& Yildirim, Z. (2008). Investigation of interaction, online support, course structure and flexibility as the contributing factors to students' satisfaction in an online certificate program. Journal of Educational Technology \& Society, 11(4), 51-65.

Yunus, A. S., Kasa, Z., Asmuni, A., Samah, B. A., Napis, S., Yusoff, M. Z. M., ... \& Wahab, H. A. (2006). Use of webcasting technology in teaching higher education. International Education Journal, 7(7), 916-923.

Zhang, D., Zhou, L., Briggs, R. O., \& Nunamaker Jr., J. F. (2006). Instructional video in e-learning: Assessing the impact of interactive video on learning effectiveness. Information \& Management, 43, 15-27.

Zhao, L., Lu, Y., Huang, W., \& Wang, Q. (2010). Internet inequality: The relationship between high school students' Internet use in different locations and their Internet self-efficacy. Computers \& Education, 55(4), 1405-1423. 


\section{Appendix 1}

\section{Constructs and Their Indicators}

\begin{tabular}{|c|c|c|}
\hline Construct & Indicators (Items) & Source \\
\hline $\begin{array}{l}\text { Perceived } \\
\text { usefulness } \\
\text { PU }\end{array}$ & $\begin{array}{l}\text { PU1: Using videos makes my learning easier. } \\
\text { PU2: Videos support critical aspects of the learning material. } \\
\text { PU3: Using videos enhances my effectiveness of learning. }\end{array}$ & (Davis, 1989) \\
\hline $\begin{array}{l}\text { Perceived } \\
\text { ease of use } \\
\text { PEU }\end{array}$ & $\begin{array}{l}\text { PEU1: Interacting with the videos doesn't require a lot of mental } \\
\text { effort. } \\
\text { PEU2: Overall, I find the videos easy to use. } \\
\text { PEU3: I find the videos flexible to interact with. }\end{array}$ & (Davis, 1989) \\
\hline $\begin{array}{l}\text { Attitude } \\
\text { A }\end{array}$ & $\begin{array}{l}\text { All things considered my using the videos in learning is } \\
\text { A1: good. } \\
\text { A2: pleasant. } \\
\text { A3: favourable. }\end{array}$ & $\begin{array}{l}\text { (Fishbein \& Ajzen, } \\
\text { 1975, as cited in Davis } \\
\text { et al., 1989) }\end{array}$ \\
\hline $\begin{array}{l}\text { Learning } \\
\text { satisfaction } \\
\text { SAT }\end{array}$ & $\begin{array}{l}\text { SAT1: I am satisfied with my learning from the videos. } \\
\text { SAT2: I find the videos to be effective in meeting the learning } \\
\text { objectives. } \\
\text { SAT3: The videos have contributed greatly to my acquisition of } \\
\text { relevant skills. } \\
\text { SAT4: The videos make me spend more time studying. }\end{array}$ & (Donkor, 2011) \\
\hline $\begin{array}{l}\text { Internet self- } \\
\text { efficacy } \\
\text { ISE }\end{array}$ & $\begin{array}{l}\text { ISE1: I understand terms/words relating to the Internet. } \\
\text { ISE2: I am confident in learning advanced skills within a } \\
\text { specific Internet program. } \\
\text { ISE3: I turn to an online discussion group when help is needed. } \\
\text { ISE4: I can explain why a task will not run on the Internet. }\end{array}$ & $\begin{array}{l}\text { (Eastin \& LaRose, } \\
\text { 200o, as cited in Kuo } \\
\text { et al., 2014) }\end{array}$ \\
\hline $\begin{array}{l}\text { Learner- } \\
\text { learner } \\
\text { interaction } \\
\text { LLI }\end{array}$ & $\begin{array}{l}\text { LLI1: Overall, I had numerous interactions related to the course } \\
\text { content with fellow students. } \\
\text { LLI2: I communicated with my fellow students about the course } \\
\text { content through different communication tools. } \\
\text { LL3: I got lots of feedback from my fellow students. }\end{array}$ & (Kuo et al., 2014) \\
\hline $\begin{array}{l}\text { Learner- } \\
\text { teacher } \\
\text { interaction } \\
\text { LTI }\end{array}$ & $\begin{array}{l}\text { LTI1: I had numerous interactions with the instructor during } \\
\text { the semester. } \\
\text { LTI2: I received enough feedback from my instructor when } \\
\text { needed. } \\
\text { LTI3: I asked the instructor my questions using different } \\
\text { communication tools. } \\
\text { LTI4: The instructor replied my questions in time. }\end{array}$ & (Kuo et al., 2014) \\
\hline \multicolumn{3}{|c|}{ Directly measurable variables } \\
\hline $\begin{array}{l}\text { Video usage } \\
\text { U }\end{array}$ & $\begin{array}{l}\text { U: How often did you use the videos? } \\
\text { Possible answers ranged from "not at all" (1) to "daily or more } \\
\text { often" (5). }\end{array}$ & $\begin{array}{l}\text { (Venkatesh, Thong, \& } \\
\mathrm{Xu}, \text { 2012) }\end{array}$ \\
\hline $\begin{array}{l}\text { Learning } \\
\text { performance } \\
\text { LP }\end{array}$ & $\begin{array}{l}\text { OUT: Your end-of-term grade: } \\
\text { Answers (from } 1 \text { to } 5 \text { ) were arranged to be the same as the } \\
\text { student's end-of-term grade.* }\end{array}$ & $\begin{array}{l}\text { (Zhao, Lu, Huang, \& } \\
\text { Wang, 2010) }\end{array}$ \\
\hline
\end{tabular}


Athabasca

University

c) (7)

BY 